\title{
Prostitution The Country's Permissible Income From the Mamulek era until the Mohammed Ali reign
}

Dr. Shaimaa Abdel Tawab Sayed Abdel Majeed

Department of Tourist Guidance specializing in modern and contemporary history

Faculty of Tourism \& Hotels - Helwan University 

الملخص:

على الرغم أن البغاء محرم في جميع الأديان السماوية إلا إن في بعض فترات حكم البلاد ساد البغاء والبغايا، وقامت هذه الحكومات بمساندة البغاء كمصدر اساسي للخزانة، فقط كان البغاء عند نشأته مفسداً ثم تحول هذا البغاء المقدس فيما بعد إلي ظاهرة اجتماعية، حلت فيها الغربة المطلقة في قضاء الثهوات محل العقيدة الدينية، وأصبح البغاء مطلوباً لذاته، ففي مصر القديمة كان البغاء المقدس على نطاق ضيق واستمر حتي عهد الرومان، فعندا أصبحت مصر تحت العباسيين ظلت بيوت البغاء موجودة بديها النساء والرجال وجاء حكم المماليك لمصر لفترة زمنية طوبلة، انتشر فبها البغاء بصورة كبيرة، وظل البغاء بصورة كبيرة، وظل البغاء خفيقاً فترة دن الزمن ثم بدأ بظهر جهراً وظل البغاء أبام العثمانيين بين مؤبدين او كارهين

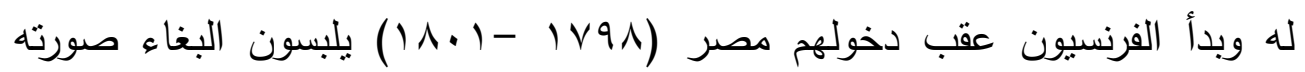
الموجودة في بلادهم، فقد قاموا بتتظيم أماكن للبغاء، وفتحوا الباب أمام البغايا المصريات للعمل في حرية تامة، دون ان يتعرض لمشاكسة الثرطة ، ومن هذا التاريخ اتخذ البغاء في مصر شكلاً رسمياُ، ولم يكن من المتوقع ان يختفي البغاء من مصر بخروج الفرنسيين، بل ففي مطلع القرن التاسع عشر، نجد أن نلاك الحرفة لا تزال موجودة ولا تزال تحظي باعتراف الحكومة، وكانت تصرح بالبغاء في أوائل حكم محمد علي، وقد استمرت هذه الحرفة معترف بها حتي عام عبما، في ضوء ذللك، تهدف هذه الدراسة إلى تتبع هذه المراحل في محاولة لإلقاء الضوء على هذه الفترات من تاريخ مصر الحديث في إطار توضبح أسباب ومظاهر البغاء والأسماء المختلفة التي أطلقت على البغايا والأسماء المنتوعة للضرائب التي كانت تفرض على هؤلاء البغايا، وما هي الصورة الجديدة التي أخذها البغاء والأسباب التي جعلت نابليون يفرض الحجر الصحي على البغي، والأسباب التي تحكمت في حكم محمد علي باشا ليصرح بالبغاء في أوائل فترة حكمه، وأيضا الأسباب التي جعلت محمد علي باشا

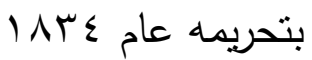


Abstract:

Prostitution is illegal according to all heavenly religions; yet during some eras,

prostitution and prostitutes spread all over the country as it was supported by the government, being a main source of income for the state treasury. At the very beginning, prostitution was sacred. Afterwards, it became a social phenomenon, in which an absolute desire for prostitution replaced the religious belief. Prostitution has become a main requirement for its own sake. In ancient Egypt, prostitution was on a narrow scale, and continued till the Roman era. During the Abbasid era, the brothels, run by men and women still existed. The Mameluke rule lasted for a long time when prostitution was disguised for a while, then it began to be public. During the Ottoman period, some people were for prostitution, others were against it. Immediately after the French invasion during the period ( 1798-1801), the French opened the door to prostitution, exactly the same as it is in France. They organized brothels, and allowed the Egyptian women to practice prostitution without any restrictions or police attacks. Since that time, prostitution had become formal. It was not expected to be banned when the French left Egypt. At the beginning of the nineteenth century, prostitution still existed, and recognized by the government. It continued to be recognized till 1834. In the light of such data, the present study is intended to follow up its different stages trying to highlight those periods in the history of modern Egypt, within the framework of clarifying the reasons for prostitution, its forms, and different names, besides the different names of the taxes imposed on the prostitutes . The study also aims to recognize the new form of prostitution and the reasons for making Napoleon quarantine the prostitutes, and the reasons for making Mohammad Ali Pasha allow prostitution at the beginning of his rule, and why he decided to ban it in 1834 . 
Instincts are human instinctive readiness, one of which is sexual instinct, that is necessary for reproduction, and species protection. The sexual instinct is not a mere pleasure, since Allah, the Almighty made marriage the only way to practice sex. Consequently man should strictly adhere to chastity and virtue, and avoid sin and vice. Besides, man should rein illegal sexual pleasure and avoid being indulged in sexual misconduct. Yet, due to the weakness of man, there are some who became vicious, and went astray. They practiced prostitution to satisfy their sexual desires. Prostitution has passed a lot of stages starting from the ancient state till the coming of Mohammad Aly, the ruler of Egypt (1805-1848). In 1834, he made prostitution illegal. Laws that criminalized prostitution were issued in 1949. Then other laws followed. In 1955 the government closed all lewd houses and those who object were arrested.

Through time some Egyptian governments supported prostitution and promoted it, others made it ineffective and made it illegal. Through time, prostitution was the main source of finance by imposing taxes on those who practice prostitution.

The aim of This study is intended to follow up prostitution through stages, since it was a source of income for the country. It also tries to shed light on legitimate prostitution during the French Campaign and the reason for imposing health and security supervision on prostitutes by the French.

There were several Terms concerned with prostitution and prostitutes It is necessary to differentiate between the different terms concerning prostitution: Prostitution of male and female, Prostitution feminine: concerning women, Prostitution masculine: concerning men, Debauchee: A man or a woman who practices prostitution and Fillesoumise : A prostitute who is licensed. ${ }^{(1)}$

Albaghaa ( prostitution) is derived from the verb (baghaa) in Arabic, which has a variety of meanings according to the context. The various meanings are : want, practice prostitution, practice aggression. ${ }^{(2)}$ 
A woman who (albaghiya), practiced prostitution in return for money (3) (*).

The legal term " prostitution" has witnessed much development in the different ages. In Greece, the term (prostasai) means standing in public in front of the house to trade their bodies. Then the Latin term (prostare) was derived from the Greek term (prostasai), which means prostitution (prostibulum) means prostitue, then (prostituo) in Latin. In the end came the term prostitute, in English and prostituee, in French. Therefore, the main elements which leads to the concept of prostitution is trading the body, which is not confined to certain clients. On that basis, all legal definitions in the past and at present, made payment a condition for prostitution. ${ }^{(4)}(*)$

Prostitution means selling a woman's body in return for money. ${ }^{(5)}$

Prostitution is a dangerous social phenomenon in the complicated societies, where individuals suffer a lot ${ }^{(6)}(*)$

There is a legal definition for prostitution, which includes three main points:- practicing prostitution as usual (punishment only for making prostitution a habit, Criminal intent, which means illegally practicing making love with a person. accordingly, the legal definition depends on:

1- Prostitution is practiced for sexual pleasure, directly in return for money.

2- A prostitute does not differentiate between clients, so long as she is paid.

3- A woman who uses her body for pleasure does not mean practicing prostitution ${ }^{(7)}$.

Prostitution means illegal sexual intercourse between male and female. The court of cassation defines prostitution saying: 
Prostitution means also making love without distinguishing, if done by a man, it is called indecency; if done by a woman, it is called prostitution ${ }^{(8)}$.

A prostitute is a woman who is professional in practicing prostitution. This term was usually used in books of language and jurisprudence. When the term prostitute is used by people or in history resources, we find it differ from time to time.

In the Mameluke era, prostitutes were called Kaynat قينات or Maghany. This is due to singing. They were also called ElKhawatee (9) الخواطيء, in the Ottoman period they were called Khawatee and obscene (AlFawahish الفواحش) ${ }^{(10)}$.

In the eighteenth century, the term fawahish was repeated. AlJabarti in his book " Ajcaib AlAthar" called obscene (fawahish (11).

In the nineteenth century, the term was used repeatedly. Besides, new names arose such as famous women, and vicious women. In the era of Ismail, a new term appeared, which stated that a prostitute lives in house of prostitution (karakhanah) كرخانة) (*) owned by a kawwada قوادة called Aykah عايقة , and the prostitude was called Maktora ${ }^{(13)(*)}$

\section{Historical roots of prostitution}

At the very beginning, prostitution was considered sacred. After that, it became a social phenomenon, in which absolute sexual desire replaced religious belief. Prostitution became wanted for its own sake, though all old names of prostitutes remained after such development ${ }^{(14)}$.

Sumer, one of the most ancient world civilizations had a number of women in their temples. Some of them were servants, others were Sarary سراري of gods or gods representatives on earth. It 
was not shameful for a Sumerian girl to serve the templates in such a way. Her father was proud to offer his daughter's beautiful body as a relief to the priests who suffer from monotony. He celebrated the day on which his daughter joined the sacred service, and offered holy communion as well ${ }^{(15)}$.

Herodotus, as well as other historians, stated that each Babylonian woman should go to Mylitta temple once in a lifetime. She never goes back home before a stranger comes, puts a piece of silver in her lap, then makes love to her asking Mylitta to protect her. ${ }^{(16)}{ }^{(*)}$. After she performs her religious duty through contacting him, she goes back home. What the man pays goes to the gods' altar as usual. Afterwards, the girls took that money to be used as dowry. ${ }^{(17)}$

Sacred prostitution continued in Babel till the $4^{\text {th }}$ century B.C, when Emperor Constantine ordered for its abolition in 235 B.C. ${ }^{(18)}$

Caledonia, Syria, and Phoenicia had such kind of sacred prostitution $^{(*)}{ }^{(19)}$. The Phoenician goddess Astrate ${ }^{(*)}{ }^{(20)}$,replaced the Babylonian goddess Mylitta, and Erech was the most important city where she was worshipped. The prostitudes were her servants. They were called Kadishtu, which means the sacred.

The sacred prostitution was practiced by the Ledians and the Persians in Mirtha temple, and Anaitis temple in Armenia in the middle of the sacred jungle. ${ }^{(*)}(21)$, Prostitution existed at the borders of Persia in the temple of Artemis. Such prostitution had spread from Asia Minor to Media and Parthia, then to Cartagena where a temple was established. Women entered that temple where they offer themselves to strangers. The temple takes a sum of money and the prostitutes keep some for their marriage expenses.

In ancient Egypt, sacred prostitution was at a narrow scale. 
One of the habits followed was to choose the most beautiful girls of honorable families in Thebes to be offered to Amon.

The sacred prostitutes consisted of a class of priestesses called god's women or Amon's women. Priestesses were divided into classes , each class had a president. ${ }^{(24)}$

Those priestesses might be the sacred Mistresses حظيات Their job was not confined to serving god only, but serving other women as well. ${ }^{(25)}$

In ancient Egypt, there were names of some famous prostitutes in certain cities. The Torah referred to some veiled prostitutes who covered their faces and waited on roads to capture men. ${ }^{(26)}$

Sacred prostitution remained in Egypt until the Roman era in which temples included a class of male and female Arqa' أرقاء ${ }^{(*)}$ whose job was to finance the temple. It was a formal source of income in temples present at Memphis and Arsinoy at that time. ${ }^{(27)}$ Ancient Greece knew three kinds of prostitutes, each has its field, rights, and standard of living ${ }^{(*)}$. The names of prostitutes varied greatly due to circumstances and traits related to them. ${ }^{(*)}(28)$

In Rome there were variety of obscenity to an extent that was unique. Among slaves in the houses of the rich, there were the sissy who provided sexual pleasure for men. Bathrooms, circus, and festivals were specially for prostitutions. Besides, male prostitution spread widely, and there were varieties of prostitutions ${ }^{(*)}{ }^{(29)}$ among them were wives and daughters of Roman emperors. ${ }^{(*)}$ (30)

During the pre-Islamic epoch, prostitutes were settled in tents, or houses with red flags called them The owner of Flags (ذوات الرايات) They paid due taxes and chose a place away from the urban areas, called prostitutes district(حارة البغايا) 
Prostitutes houses have existed during the Abbasids era , run by men and women. They spread in Baghdad and other cities. They were called Al Khshakhinih الكثاخنة. (32)

After the Arabs entered Egypt, prostitution was hidden for a period of time, then it appeared. The taxes AlMakus (المكوس) imposed by King AlAziz Bellah Emad Eldin Abulfath in the end of the sixth century( Hijra) included taxes on prostitution .

In 648 the minister AlAsaad Shraf Eldin Abulkasem in the epoch of King Aybak Alturkumani, imposed taxes on the prostitution houses, called (the sultanate rights and divan affairs). Besides, there were the (Sudan rights), imposed on each slave who came to practice prostitution. ${ }^{(34)}$

ALZaher Bibars ordered closing prostitution houses in $665 \mathrm{H}$., and dispelled professional prostitutes, and banned the taxes imposed on prostitudes, one thousand dinars per day.

Immediately after the death of ALZaher, prostitution came back, controlled by a woman called the sponsor (الضامنة) . She was in charge of collecting taxes from the prostitudes. She paid the government share. This was called sponsor of the Ghawany ضامنة ) (36) (الغوانى او المغانى)

Sultan Qalaun, banned the sponsor of Ghawany during his third reign 705-741H., After his reign finished, prostitution came back till King Al Ashraf and King ALZaher Barkuk came and banned it in 790H. in Egypt. ${ }^{(37)}$

So, the kings and sultans of Egypt during the Mameluke era were divided into pros and cons of prostitution .

Prostitution was still between pros and cons during the ottoman period. When the country faced disaster, Crisis and diseases 
prostitution was banned, and prostitutes were severely punished ${ }^{(*)}$ ${ }^{(38)}$, when disaster came to an end, prostitution came back.

In the seventh century A.D, all prostitudes were subjected to a new system. Their names were registered by the police registrar Al Swbashy (الصوباشى) who kept and registered the names of the professional women Prostitutes and collected the taxes imposed on them ${ }^{(*)}{ }^{(39)}$, In the eighth century A.D, such taxes were returns for the governor, wali. It was the main income for him. Prostitution and prostitution houses were threaten till the the French campaign in 1798 came. A new page was opened for the history of prostitution. ${ }^{(40)}$

The French, immediately after invading Egypt, 1798-1801, started to make prostitution similar to it in France, and opened the door in front of the Egyptian prostitutes to practice their role openly away from threats of the police. Since that time, prostitution had become legal ${ }^{(41)}$.

It was unexpected that prostitution would disappear by the departure of the French. In the beginning of the twentieth century A.D, such a profession still existed and was supported by the government. Prostitution was allowed at the beginning of Mohammad Ali era. ${ }^{(*)}{ }^{(42)}$

The government imposed taxes on prostitutes called Alkharda (الخردة). In some years its sum was 800 bags of money. This tax was collected under item of (revenues of dancers, musicians and charmers). The man in charge of the taxes was called the contractor of Alkharda. He had to pay a fixed amount of money to the government. (43)

Such profession was still recognized till the year 1834. Lean stated that Mohammad Ali issued directives in the first week of June 1834 that prostitution should be banned. Those who violate the directives should be punished by being hit with a whip 50 times. She 
who returned should be punished by being prisoned for a year with hard labor) ${ }^{(44)}$

That was not the end of prostitution in Egypt. It was just a new page in the history of prostitution, which turned to be secret . Then it appeared in the era of Saed. In the era of Ismail, it flourished, as if it was formal.

In the era of Tawfik, laws that allowed prostitution were issued for health reasons. During the British occupation in 1882 , a new page in the history of prostitution was opened. It was called " formal or permission prostitution period". ${ }^{*}$, 1882 permit was not the only one. In 1885 , the regulations of the office for inspection of prostitutes were issued. Then 1886 the brothels regulations were issued. ${ }^{(45)}$

There were many attempts to fight prostitution and close down brothels . It was Abdullah ALNadim who waged war against it in "Alustaz" newspaper. ${ }^{(46)}$, the movement of El Sheikh Abu El oyoun waged war against prostitution in the newspapers since $1923^{(47)}$, And also Huda Sharawi fought it, showing its disastrous influence on society. She mentioned Islam opinion concerning it.She waged war against prosititutes and prostitution. ${ }^{(48)}$

Such regulations were still in effect till a new more comprehensive one was issued in 1905 . It had been in effect till it was canceled in 1949 by the military order no. 76,1949 which stated that brothels should be closed down. This was the end of formal prostitution in Egypt. It became a crime punished by law. ${ }^{(49)}$

In 1950, law 50, 1950 concerning abolishing traditional laws all over the Egyptian kingdom, except for Sinai and the Red Sea was issued. So, it was necessary to issue a new law to replace the military order which banned the formal prostitution. Accordingly, the ministry of Mustafa El Nahas Pasha issued law 68 in 1951 concerning fighting prostitution $^{(*)}(50)$ 
In 1953, article 10 repeated, was added to the this law to determine the procedures for monitoring the crimes of prostitution, then , article 269 repeated was added to the penal code, based on law 568 in 1955 which states punishment of those who provoke lewdness. It is the law which is still effective. The prostitute should not be punished without bringing legal action by husband. Anyway, there was a law that considers prostitution a crime for the first time in Egypt. ${ }^{(51)}$

\section{Prostitution and prostitutes in the eye of heavenly legislations:}

Heavenly religions ( Judaism, Christianity, and Islam) warned us of any illegal relationship, and those who practice it are to be severely punished.

In Torah, prostitution was mentioned a lot of times, which reflects lewdness which spread among Israeli people after leaving Egypt. So, the Torah texts posed strict rules to protect people. If a man committed adultery with a married woman, he would be sentenced to death. If a virgin committed adultery, when she was still at father's home, the city men would stone her till death. If an engaged woman committed adultery with another man, both would be stoned till death. If a woman who wasn't engaged committed adultery with a man, that man would pay her father fifty silver coins, and be her husband forever. In the Jewish shariah, marital infidelity and adultery are illegal. ${ }^{(52)}$, in Bible,

Jesus, PBUH, did not come up with new rules in the field of sexual conduct as his teachings were based on the Torah laws.

Jesus, commented only on the end of the Ten Commandments saying: "Whoever has an erotic look at a woman, he commits adultery by heart". Christianity was based on tolerance .It means that the method of repentance excels the method of punishment .Consequently, Jesus forgave Mariam El Magdalea, who was a well known prostitute, and said to her: You are forgiven, due to your belief, go peacefully. 
Christianity called for the overwhelming of the soul over the body, and purity of the self, soul and body. It also called for the sacred marriage, and rejected anything that contradicts with this sacredness. ${ }^{(54)}$, And The Qur'an, It is well known that prostitution is illegal in all religions. It's considered adultery which is absolutely prohibited according to the Qur'an verses. Islam imposed punishment on the person who practices adultery if not married.

The woman and the man guilty of adultery or fornication,- flog each of them with a hundred stripes: Let not compassion move you in their case, in a matter prescribed by Allah, if ye believe in Allah and the Last Day: and let a party of the Believers witness their punishment married, he would be thrown with stone till death. ${ }^{(55)}$, Adultery is strictly illegitimate in Islam. Allah, the Almighty said: Nor come nigh to adultery: for it is a shameful (deed) and an evil, opening the road (to other evils) ${ }^{(56)}$

The above text considers all forms of adultery illegitimate, yet Allah, the Almighty stressed that girls and women should never ever be forced to practice prostitution for money. Allah, the Almighty said

Let those who find not the wherewithal for marriage keep themselves chaste, until Allah gives them means out of His grace. And if any of your slaves ask for a deed in writing (to enable them to earn their freedom for a certain sum), give them such a deed if ye know any good in them: yea, give them something yourselves out of the means which Allah has given to you. But force not your maids to prostitution when they desire chastity, in order that ye may make a gain in the goods of this life. But if anyone compels them, yet, after such compulsion, is Allah, Oft-Forgiving, Most Merciful (to them) ${ }^{(57)}$,Prostitution in the verse means practicing adultery as a profession for money. No doubt that forcing women to practice prostitution for money is the main form of woman 
humiliation in particular, and humanity humiliation in general. So, the Islamic Shari'ah considers prostitution illegitimate ${ }^{(58)(*)}$

\section{Prostitution in the Mamluke era, its Reasons and its features in Egypt:-}

Prostitution has existed since the very beginning of history. All heavenly religions consider it illegitimate. Prostitution had a different from in the Mamluke state. It was considered a source of money, and confessed it. Prostitutes were provided with formal care in return for tax payments. It was a source of much money, which not happened for the first time in Islam. Some sultans of the Mamluke rejected prostitution, others supported it and encouraged tax payments, which helped spread prostitution. Prostitution policy in the Mamluke state was sometimes rejected, and sometimes accepted till the fall of the Mameluke state in 1571.

The age of the Mameluke sultans is characterized by social and ethical contradictions due to their history and policy. We find some of them religious such as Al Nasser Mohammad Ibn Qaloun who banned taxes on illegitimate activities. On the other hand, there were others who were extremely obscene such as sultan Barkuk who made wine a motto of his state. ${ }^{(59)}$

No doubt that the dictatorial government aims to make people surrender through losing dignity, principles and virtues. Consequently, people indulge in vice and become a prey to be easily governed by tyrants. ${ }^{(60)}$

The Mameluke failed to govern the Egyptians manners. At the same time, they were indulged in dissipation. So, a lot of Mameluke gathered much money, and owned all that was precious through tyranny and bad treatment of Egyptian farmers, merchants, and seniors. They introduced the policy of expropriation, and taxes for the sake of getting as much money as they can .Some Mameluke sultans went to extremes in spending such money on dissipation. ${ }^{(61)}$ 
The life of a lot of Mameluke sultans was full of extravagance, and dissipation, though some of them pretended to be pious to deceive the Egyptians. ${ }^{(62)}$ Such as Sultan AlMalek AlMansur Aba Bakr Ibn AlMalek AL Nasser Mohammad Ibn Qaloun ( 1340-1341) who spent his nights in dissipation. ${ }^{(63)}$, He used to make gatherings attended by prostitutes ${ }^{(64)}$

Sultan Almalek AL saleh Ismail Ibn AL Nasser Mohammad (1342-1345) who was interested in black slaves, night club ladies, and singers. He was distracted from the state's affairs, and was indulged in women and slaves who were the way to jobs. ${ }^{(65)}$

Sultan AlMalek Elkamel Shaaban Ibn AL Nasser Mohammad (1345-1346) in whose period profligacy and dissipation spread. He was indulged in dissipation and spent a lot of the people's money on it. (66). His policy led to his country's destruction since he was indulged in drinking and disgraceful acts publicly. He enabled women to rule the country. All the Egyptians acted wrongly due to his indifference. He said: "Let each person do what they like ". (67)

Sultan AlMalek AlMuzaffar Hagi (1346-1347) was indulged in dissipation $^{(68)}$, which made him worse than his ancestors. The drought which the country suffered did not prevent him from avoiding disgraceful acts with singers and servants ${ }^{(69)}$. He was indulged in dealing with morally defected people publicly ${ }^{(70)}$.

Sultan AL Nasser Hassan ( 1347-1351) (1354-1360) was fond of women and servants. He accompanied them in his travels.

AlMalek AlMansur Mohammad Ibn ALSultan AlMuzaffar Hagi (1361-1363) . He used to make fun with the wives of the princes and have pleasure with them, he put cakes in a box to sell them to women out of fun and dissipation. He was not punctual in prayers. ${ }^{(71)}$ The sultans used beautiful young boys for service and pleasure as well. Besides, they made them Jumdariyah (جمدارية) ${ }^{(*)(72)}$ for them ${ }^{(73)}$. 
Ibn Hagar said that AL Nasser Ahmed Ibn AL Nasser Mohammad Ibn Qaloun was deeply in love with a handsome young boy, and made love to him. The sultan gave orders to kill that boy. AL Nasser saw that it was a severe punishment and threatened that he might kill himself, and stopped eating till the boy was free ${ }^{(74)}$.

Sultan Al Ahraf Shaaban Ibn Hussien Ibn AlMalek AL Nasser Mohammad made sexual relationship with beautiful Mameluke women. Princes made the same. Male sexual relationship spread at the time ${ }^{(75)}$.

The history of the Mameluke Sultans in Al Barjia country (1382-1517) witnessed extravagance and dissipation ${ }^{(*)}(76)$.

The Mameluke followed the Sultans, and lived a life of extravagance since they were very rich as mentioned in the books written at the time. They owned beautiful slaves, singers and handsome boys of different nationalities. They went to extremes in dissipation. Moreover, they sexually harassed the families daughters in public without deterrent .

The Sultan El Zaher Bibars (1260-1277) saw that by himself when he disguised and went out of the citadel at night. He had a walk around Cairo to check people's lives. He noticed sexual harassment. He saw a prince who obliged a woman to take off her pants. He couldn't deny that ${ }^{(77)}$.

If that was the case of most Mameluke sultans, and princes , it's normal for people to imitate them, since people follow their rulers . As a result, corruption and dissipation spread all over Egypt. ${ }^{(78)}$

The sultans were indulged in corruption and dissipation , and failed to control the conducts of the Egyptians, and punish those who deviate. They went to extremes in corruption and dissipation. They made prostitution a profession which received care and support on part of the government. Taxes were imposed on those professionals. This was an important source of money for the government. ${ }^{(79)}$ 
This tax started at the beginning of the Mameluke era when Sultan Ezz Eldin Aybak (1250-1275) appointed AlWazir AlAssad Sharaf Eldin Hebatullah Ibn Saed Alfaezy ${ }^{(*)}$, who had a bad influence on people. He encouraged the spread of brothels, wine and drugs such as opium and imposing a tax on prostitutes. He called that (the sultani rights and divan affairs).

Consequently prostitution was recognized by the government, and prostitutes were supported. The government assigned damenah $^{(*)}$ for them ${ }^{(81)}$ who was considered a boss. ${ }^{(*)}{ }^{(82)}$ A professional was registered by the damenah. The damenah paid money to the government. She also got money from the prostitutes as taxes in return for the government support and care. ${ }^{(83)}$ So, the government paved the way to dissipation. In the time of formal prostitution , parents were unable to prevent their daughters from being indulged in dissipation ${ }^{(84)}$.That led to expansion of white slave traffic to provide brothels with prostitutes ${ }^{(85)}$

That the government protects brothels is against ethics and morals, since it imparts legitimacy to prostitution, so the prostitutes are encouraged not to repent. Besides, indifferent men are encouraged to go to such places. This shows how the government encourages dissipation, not fighting it ${ }^{(86)}$, which contradicts with the verse:

\section{Allah commands justice, the doing of good, and liberality to kith and kin, and He forbids all shameful deeds, and injustice and rebellion: He instructs you, that ye may receive admonition. (87)}

Consequently, prostitution spread in the Mameluke era to the extent that prostitutes existed in the market place and other places in public asking for sexual relationship.

This was not confined to Cairo and other big cities. It existed in upper and lower Egypt, and villages as well. There were avenues where singers and prostitutes practiced their actions and wine was drunk publicly. Even if a stranger happened to pass by such places, he 
was obliged to make love with one of the prostitutes, or pays her money so she pay the due taxes every day. In cities, one floor houses were built for dissipation. Laws were issued to close such places, yet they were re-opened) ${ }^{(88)}$

The woman in charge of selecting singers and prostitutes (damenah) chose from amongst the most beautiful women who had beautiful voice and were well trained in how to attract the audience and get as much money as they could. ${ }^{(89)}$

There were more than one (damenah) in Egypt and Belbis for prostitution in the Mameluke era who wore a certain uniform AlMakrizy narrated about the Shamaeen market that shops there were open till midnight. In the shop were prostitutes called Zairat Alshamaa'in (زعيرات الثماعين). They wore a special uniform to be recognized. They wore sheets, scarfs and red pants.

Prostitutes had a distinguished way of walking, and combed their hair differently, which was not legal. ${ }^{(90)}$

It is thought that such prostitutes were obliged by deteriorated economic status ${ }^{(91)}$ since they found out that it was the only source for money so as to survive. It shows that the prostitutes had a very bad life. ${ }^{(92)}$

No doubt that prostitution reflects the society's viewpoint of women at that time. Man has had considered women a source of personal pleasure rather than a partner in life. For some people, women were looked upon with sarcasm and humiliation (93)

The existence of a lot of slaves in Egypt and the Levan who offered pleasure for men reflects a picture of women in that age, Their big number encouraged the spread of prostitution and brothels in Egypt $^{(94)}$. There were European prostitutes in Alexandria who were called Bota بوطا 
Prostitution in the Ottoman period, its Reasons and its features in Egypt:-

The same status continued in the ottoman period approximately. It extended for about three centuries (96), and prostitution spread in Cairo and other big cities.

In Cairo, ALAzbakia was a focus of prostitution though it was a resort for the aristocratic class. The cafes at Wagh el Berkah were used for dancing, and singing. They were clubs for pimps. The Gypsies and Al Jaidiyah communities spread widely. As their wages level was suitable for the poor, a lot of people went there. Their café were crowded with people, particularly craftsmen, workers, and farmers who came from Cairo suburbs for pleasure after hard work. Wagh el Berkah was a place for the thieves and the dishonest. Its narrow avenues were crowded with women who were thieves and prostitutes as well. A variety of women mobs spread there such as the wild cow (بقر الوحش) and antelope (والبقر السارح) · ${ }^{(98)}$. ALAzbakia was not the only place for prostitution, since references stated that there were brothels on the hill near Attibi mosque in old Egypt ${ }^{(99)}$. Also, there brothels near Berket el Megawerin near ElMadbah where there were a lot of brothels ${ }^{(100)}$. Besides, Babelluk was crowded with prostitutes $^{(101)}$.

In Damietta, and other touristic cities, such as Rashid and Alexandria, there were brothels called Mawakef (مواقف) . The owner of the brothel paid money to the government, then took it back from the prostitutes who work in his brothel.

Men of authority had played a vital role in attracting prostitutes and taking money from them . They also assigned them the brothels. The spread of the brothels in the ottoman period was accompanied by the spread of pubs ${ }^{(*)}$ (الميخانات) particularly in Damietta, Rashid, and Alexandria. Some pashas closed down the pubs, others reopened them ${ }^{(102)}$, a lot of travelers who visited Egypt during the ottoman 
period stated that prostitutes were found in other cities, Sonnini stated that Damanhur had a lot of prostitutes . They were unveiled. They existed near cafes in tents to attract people. There were prostitutes in Gerga, Minya, and Assuit, at the beginning of the nineteenth century. Burkheart pointed out that there were about 300 a Bramkeh woman in Menya ${ }^{(103)}$.

It is worth mentioning that prostitutes in the ottoman period had to pay taxes called khardah, a tax imposed on night clubs, prostitutes, dancers, and charmers and others. The man in charge of them was called Amen khardah (أمين الخردة) (104)

The man in charge of the prostitutes was called Al Sobashy الصوباشي, who was the head policemen known as wali or the leader. Prostitutes were registered by Al Sobashy الصوباشي. They paid him the due taxes. About forty sergeants were in charge of the prostitutes. They knew well the brothels in the city and have full control over the prostitutes, even they knew if the prostitutes slept at home. ${ }^{(105)}$

Near the middle of the seventeenth century A.D, the man in charge of the taxes was called Amen Shakar(أمين شكار) . He continued to be in charge of them till $1053 \mathrm{H} / 1643$ AD. The job was cancelled in that year ${ }^{(106)}$. When the taxes came back in the eighteenth century, they were given to the wali, the Agha of the police, and the Turkish lieutenants. The wali's own income was the taxes.

The taxes were not fixed, and the brothels were at a loss . They were opened by a wali, then closed down by another, and so on. The first wali to do that was the vizier Hussein Pasha, known as the mad man. He closed down the brothels in Egypt (107), afterwards, prostitution spread again in the Egyptian cities and villages as well. Whole tribes such as Ghawazy and Bramkeh (الغوازي والبرامكة)became professional prostitutes, and others. The government imposed taxes on them, which did not satisfy some walis who tried to ban it. One of them was the vizier Maksoud Pasha who stated that the money taken 
from dancers and singers should be banned. He canceled the job of Amen Shakar ${ }^{(108)}$, as usual, prostitution came back and brothels spread in many places, and the policy of the government was to survive it, and continue to impose taxes. This state continued till the coming the French campaign to Egypt in 1798 when a new page in the history of prostitution in Egypt was opened.

\section{Prostitution during the French expedition, its Reasons and its features in Egypt:-}

When the French campaign came to Egypt, prostitution was encouraged since the French brought with them about 300 women, the most beautiful of them were for some soldiers. The officers took the Mameluke women. General Pirre pointed out that the Mameluke princes provided them with some beautiful Armenian and Karjiat (كرجيات)women who were captured. ${ }^{(109)}$

The French women and the slaves were not enough to satisfy the sexual desire of the army soldiers. So, it was a golden chance for the prostitutes and to practice their job. So the prostitutes and vendors were the first to appear to deal with the French. ${ }^{(110)}$

The French organized the brothels and opened the doors for the Egyptian prostitutes freely without facing any troubles on part of the police as the case was in the previous eras ${ }^{(111)}$. Al-Jabarti stated that in November 1798 A.D, after three months of the French occupation of Cairo, the French established in Bighayd al muwbaa بغيض النوبيnear to Al azbakia buildings in the form of park, women and men meet at specific times. It was a place for pleasure and dissipation. Those who attended had to pay. ${ }^{(112)}$ Such places were organized for the French prostitutes who came with the French army.

As for the Egyptian prostitutes, the French imposed health censorship on them. They were also registered. Soldiers were obliged to deal with the registered only for safety purposes to avoid conspiracies or assassination. Since that time, prostitution had been legal. The French registered the names of the pimps, and made them 
in charge of the French soldiers. Since the French soldier did not feel safe when he entered a large house, it was better for the soldier to be near the prostitute who exists in a shop for safety in case of danger . (113)

The French ordered each prostitute to put a lamp over her shop, and write down her wage. As it was difficult to write in French, the prostitute used symbols instead of language. They immersed their hand in a red liquid, then printed her hand on the façade of the shop, which meant five. If two hands were printed it meant ten. The Buffon (Khalbus) خلبوص was also paid for receiving and welcoming guest ${ }^{(114)}$ The Egyptian prostitutes were many and cheap. A lot of them, as Herald stated, were not attractive .They were ugly and diseased, yet a lot of them appeared in the French camps. ${ }^{(115)}$

The natural result for such facilities was the spread of syphilis and gonorrhea diseases ${ }^{(*)}$. The French physicians tried to control such diseases, but in vain. It was due to the fact that the French soldiers were eager to practice sex with the prostitutes as a lot of the soldiers missed family life. ${ }^{(116)}$

So, the leaders tried as hard as possible to fight such diseases by treating the Egyptian prostitutes . General Digia wrote a letter to Bonaparte , after he noticed the Egyptian prostitutes had infected the French soldiers. Digia wrote: The prostitutes caused epidemics in the French houses. They should be drowned in the camps to get rid of them". Bonaparte ordered to assign the Agha to perform the task ${ }^{(117)}$. As a result, four hundred heads of the prostitutes and singers were cut off and thrown into the River Nile. In his book, the Medical History of the Eastern Army, Desgennete tried to make Bonaparte innocent, saying that Bonaparte issued that decision to the Agha to treat the women in the military hospital ${ }^{(118)}$, anyway, this didn't mean that Bonaparte was against prostitution as he, immediately after having occupied Cairo, the first item in the list sent to France was one 
hundred French prostitute for the pleasure of the soldiers ${ }^{(119)}$, A few hundreds of prostitutes and slaves was not enough for the pleasure of the big number of the soldiers. So, the French tried to bring more women in all ways. After the second Cairo revolution, the French obliged a big number of Boulak women to be prostitutes ${ }^{(120)}$

Al-jabarti described the interest of the prostitutes and slaves in the French soldiers in many on many occasions. He stated that they were obscene ${ }^{(121)}$. Dr. Luis Awad considered the word" obscene " an ethical characteristic, and a personal viewpoint, not a name of a certain class or profession. ${ }^{(122)}$. He aimed to state that the Egyptian women found out that the French campaign was a chance to be free from the restrictions imposed on women and to be free from the tyranny of eastern men. Al-Jabarti attacked such women and called them obscene. He talked about the prostitutes who are called obscene on many occasions during the French campaign and during the era of Mohammad Ali. ${ }^{(123)}$

\section{Prostitution in the era of Mohammad Ali till banning it in 1831:-}

It was unexpected that prostitution would disappear when the French left Egypt. In the beginning of the nineteenth century, we found out that prostitution still existed and recognized by the government. Such profession had supervisors and regulations ${ }^{(124)}$. The number of prostitutes had increased in Cairo superbs, even in $\mathrm{Al}$ azhar area, which made people complain and call for dismissing them ${ }^{(125)}$

During the first part of the reign of Mohammad Ali, prostitution was encouraged by the government. The policy followed by Mohammad Ali was to collect money and taxes to achieve his objectives as the government imposed the khardah taxes on the prostitutes. The sum of money collected in some years was 4000 pounds, one tenth of the money collected from all Cairo residents, according to Edward William Lean ${ }^{(126)}$. That tax was under the item "returns of dancers, musicians and charmers:. Al-rafei stated that 
revenue of such tax was 2500 pounds in $1833^{(127)}$. That sum contradicts with the sum mentioned by Lean . Anyway, Fouad Shukry said that the revenue in 1833 was approximately 4500 pounds. Acerbi, the Austrian ambassador in Alexandria submitted a report to the government showing that the revenue was 3600 pounds in $1827^{(128)}$, The man in charge of the tax collection was called the khardah contractor. In return, he paid a fixed sum of money to the government. Such profession was still recognized till the year 1834 . Lean stated that Mohammad Ali issued directives in the first week of June 1834 that prostitution should be banned. Those who violate the directives should be punished by being hit with a whip 50 times. She who returned should be punished by being prisoned for a year with hard labor ${ }^{(129)}$, Clot Bey commented on this saying that the government banned taking revenues from prostitutes and decided closing down prostitution houses, and stopped recognizing them as it was shameful ${ }^{(130)}$, at any way, this was not the end of prostitution in Egypt. It was just a start of a new page in the history of prostitution called the era of banning as it became illegal by law. Yet, prostitution still existed. Such decisions did not completely ban prostitution as it existed at all times in all societies. The decisions could only hide the formal shape of the profession as it turned to be secret. The names of prostitutes were not registered in the documents during the age of Mohammad Ali and Abbas. Then prostitution came back in the age of Saeed . (131) 


\section{Conclusion}

The study showed that prostitution went through a lot of stages and governments. During the Mameluke era, some sultans and princes supported prostitution, others banned it. During the Ottoman period it was nearly the same. Prostitution still existed in Egypt till the coming of the French campaign. Then laws were issued to protect prostitution in Egypt. Napoleon imposed taxes on prostitutes and other professions to face the difficult problems in Egypt. Prostitutes were placed under guardianship to protect the French soldiers against sexually transmitted diseases. Prostitution still existed during the age of Mohammad Aly for the sake of collecting money. Prostitution still existed since 1805. In 1834 he banned it. During the era of Mohammad Aly sons and grandchildren, we found out that some of them supported it, whereas others banned it.

Under the British occupation in 1882 , a new page in the history of prostitution opened. It has become formal. The military order in 1949 and laws 1950, 1951, 1953, 1955 banned prostitution . For the first time in Egypt there was a law that considered prostitution a crime.

The Mameluke considered prostitution a source of financing the government, so prostitutes were recognized by the government. Besides they were provided with care ,The Mameluke considered prostitution legal as it was a main source of income for the government. Prostitution had existed since the very beginning of history. It was sacred, based on religious principles as it was considered a pleasure for priests. When the Mameluke came, they protected and supported prostitution, which still existed even after the fall of the Mameluke.

The Mameluke sultans didn't know that prostitution led to the fall of their government as they depended completely on the prostitution taxes. What a shame! The Mameluke government fell, yet prostitution still existed. It was inherited by different governments in Egypt.

Governments did not realize that prostitutes tax was the main reason for their fall though the names of the taxes were varied. Such dirty money was the main reason for destruction, consequently, all heavenly religions ( Judaism, Christianity, and Islam) banned all 
forms of prostitution and imposed severe punishment on those who practice it. Islam banned all drugs and wine since they lead to obscenity, and the destruction of societies.

It has become clear cut that prostitution was a source of money for all the governments that ruled Egypt, starting from the Mameluke to the end of Mohammad Ali era who banned it .After that England considered prostitution legal for the second time after Napoleon. It was formally banned in 1955. 


\section{References}

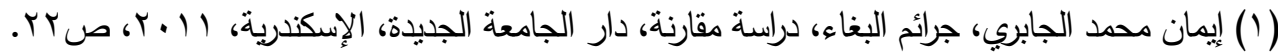

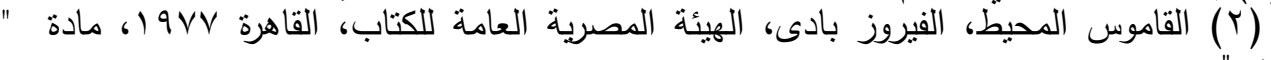

(بَّ) ابن المنظور : لسان العرب، ط ثالثة، تحقيق إبراهيم الزيبق، دار احياء التراث العربى، مؤسسة

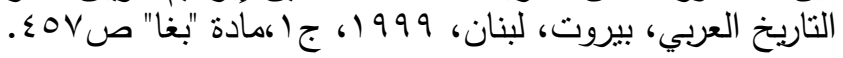

(*)A prostitute is a slave, whether a whore or not. Others state that she is a whore, free or a slave. In the holy Quran, " your mother was not an unchaste woman ", which means she was not a whore. It is well known that the mother of Mariam was free. Others stated that it means the servants, since they used to be whores. It is said : "the prostitutes were in the front ", which means the servants.

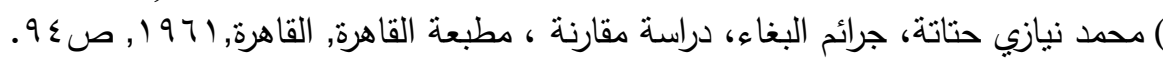

(*) Prostitution means the process in which sexual intercourse is not legal, as it does not aim to maintain species. It just aims to satisfy an individual desire.

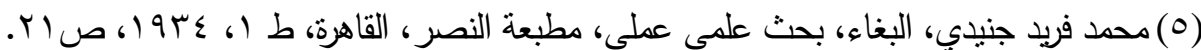

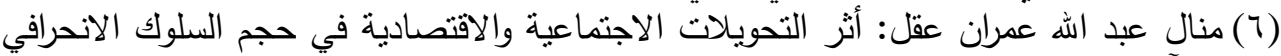

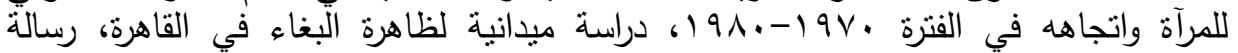

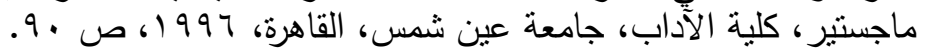

(*)The city is the clear-cut model for a complicated society. Consequently, prostitution spreads clearly within the sight of those responsible for the public order.

(V) رضوي فرغلي، بغاء القاصرات، دراسة في ضوء التحليل النفسي، مركز المحروسة للنشر

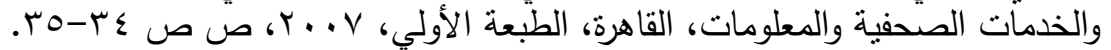

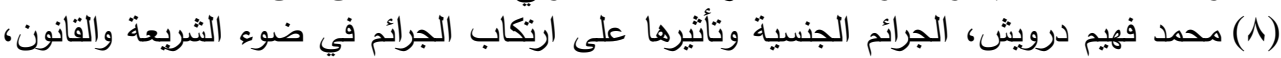
دراسة علمية موثقة بتطبيقات المحاكم وكيفية مكافحة الانحرافات الجنسية، دارية دار داووده، القاهرة،

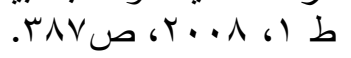

(9) البيومي اسماعيل، النظم المالية في مصر والثام زمن سلاطين المماليك، الهيئة المصرية

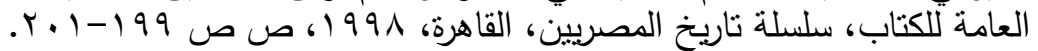

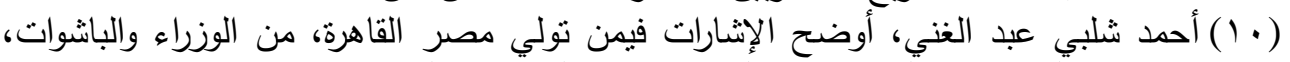

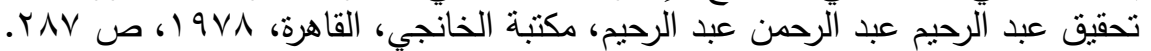

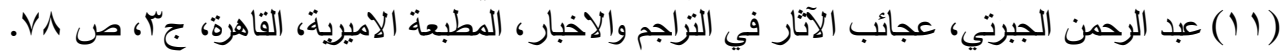

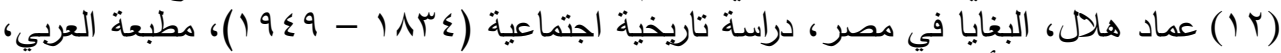

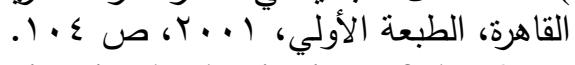

(*) Karkhana term is a house of prostitution in the beginning of the Ottoman period. During that time the prostitutes practiced the profession in brothels. 
Besides, there are other names such as whorehouse مواقف, but the karkhana was the most famous during the nineteenth and twentieth centuries.

$$
\text { (1) (1) نفسه، ص ص 11 (1) }
$$

(*)We should differentiate between whole-time and part-time prostitutes . Part time prostitutes had an additional legal profession to earn her living. There were also occasional prostitutes, her circumstances allow her to practice prostitution, then she goes back to her main job, whether she stopped practicing prostitution or not.

(14) Gordon, Pierre, sex and religion, translated by renee and hilda, sondheim, N.Y. 1949.

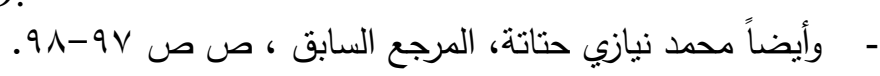

(15) Barag, G.; Zur Psychoonolyse der prostitution, Imago, 1937, P. 330.

(16) Ellis, Havelock, Studies in the psychology of sex, Vol. 2, Part 3, N.Y Random house, 1937, p.25.

(*)Women were not allowed to refuse the silver given to them regardless of its value. They had to accept the stranger who wants her at any rate. A beautiful woman always succeeded in her profession, but an ugly woman used to stay for three or four years in the temple before she did the job.

(17) Moris JAstrow, the religion of Bablylonia and Assyria, London, 1898, P.475.

(1) ول ديورانت، قصة الحضارة، ترجمة زكي نجيب محمود، لجنة التأليف والترجمة والنشر ، ج؟،

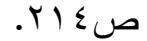

(*) The old texts of the Phoenician the Assyrians and the Chaldeans show that prostitution speared in the big eastern cities, the majority of people tended to let their weaves practice prostitution in hard times as such people were abnormal.

(9 (1) أنطون زكري، تحريم البغاء عند قدماء المصريين، وحصن الحكومة على الغائة، مطبعة

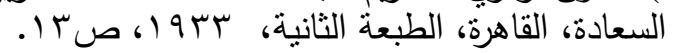

(*) The goddess Astaite was the goddess of fertility and the mother's goddess

(20) Morris jastrow, loc. Cit, p.480.

(*) Foreigners only were allowed to enter such forests, where the prostitutes collected the dowries of their marriage.

(21) Gordan, Loc. Cit. p.48

(22) Bonaparte, Marie: sexualité de la femme, presses universities de France, Paris, 1957, p. 46,47.

(*)The Pharos in Egypt used to favor chastity and morals, to prevent corruption in case of indifference. People realized that inclination 
towards chastity. Ramses, the third was considered a guard who did his best to guarantee women dignity and chastity.

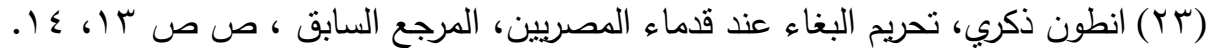

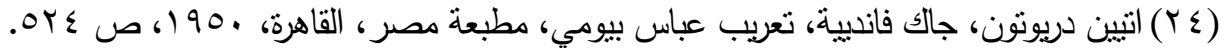

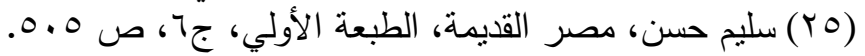

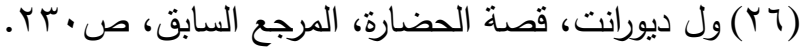

(*)Those servants (Arqa') were called Hierodouloi. They were professional prostitutes. They were either born to be servants or free. They were devoted to temples to be rewarded or to be forgiven for their worldly sins.

(YV) إبراهيم نصحي، تاريخ مصر في عصر البطالمة، لجنة التأليف والثرجمة والنشر، القاهرة،

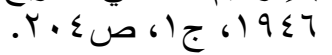

(*)The Dicterida class was the lowest class of prostitutes . They used to live in Dicteria, a brothel, established by the Greek legislator Solon who established a temple financed by the prostitutes. The temple was run according to rules. The Hetairae class was the highest one. The Aulitride class, or the singers class were similar to the opera artists in our time.

(*)The houses that follow certain rules were called Ergasteria, Paidiseia, Porneia, or Oikemate. Besides them were houses opened by foreigners. Prostitutes were called Klysigelkes, or the crying women as they used to cry when they met men . They were also called Sestors because they took all the money in the purses of men.

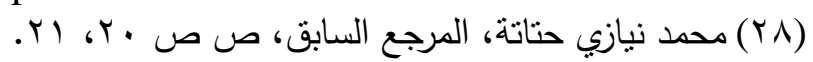

(*) Prostitutes were called prostibuloe. Those registered were called Metertrice, and those who were not registered were called Delicatoe, who benefited from the money of their lovers. The Femosoe were those who came from respectable families. The Doris were those who used to be naked due to their beautiful bodies. The Lupa were the woods dwellers. The AElicarioe were those who offered the gods immolation. The Bstuarioe were tombs dwellers, the Copoe were the pubs attendants , the Noctiluoe were the night wrangler, who were the lowest class, the Quardantarioe, the worst prostitutes, and the Gallinoe, who were professional thieves.

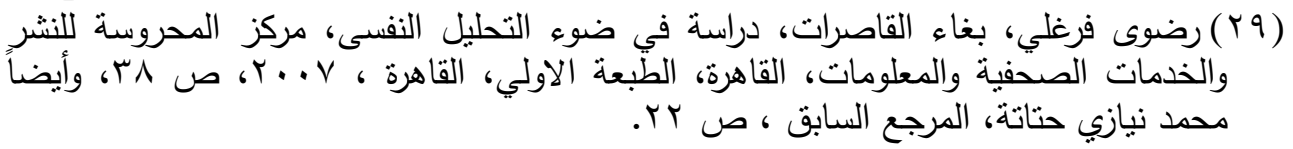

(*) Flafia Domitia, the wife of Visbesian Misalin was among the prostitutes.

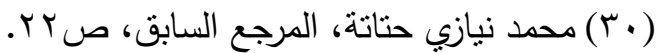

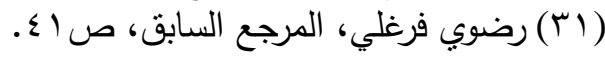




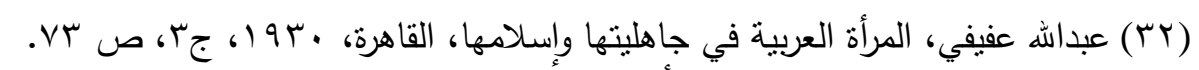

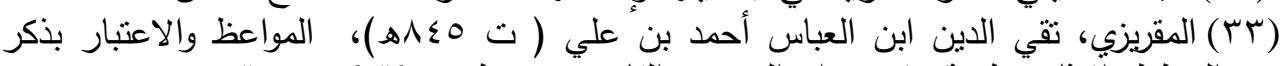

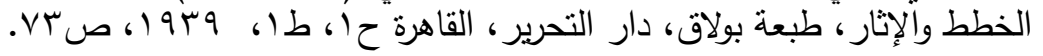

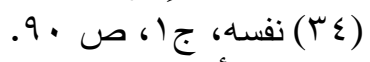

(ro) ابن أياس، محمد بن بني أحمد بن أياس الحنفي، بدائع الزهور في وقائع الدهور، تحقيق، محمد

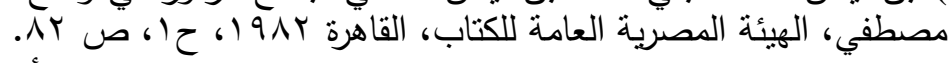

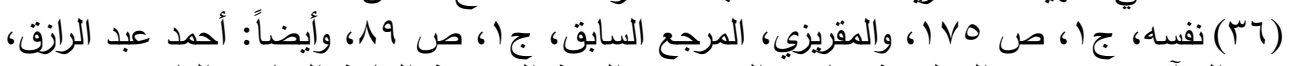

المرآة في مصر المملوكية، تاريخ المصرين، الهيئة المصرية العامة الكتاب، القاهرة، 1999 المبن،

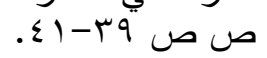

(37) Sanger, William W., The History of Prostitution, New York, Arno press, 1972, P.88.

(*) When the Nile water decreased in $854 \mathrm{H}$., The Sultan asked people to avoid being sinners. They asked them to fast, like the prophet Dawood, who used to fast was every other day. When the Nile water stopped to increase in $866 \mathrm{H}$. ,the Cairo ruler closed down all brothels and night clubs. Besides, he arrested all people in them. During the era of Sultan Qaietbey Almahmoudy, when the Nile water decreased in $875 \mathrm{H}$., the Sultan ordered that all people should avoid being sinners, otherwise they should be severely punished. In $919 \mathrm{H}$. when plague spread, Alsultan Alghoury ordered that wine, opium and prostitution should be banned. This call continued for three successive days due to the spread of plague.

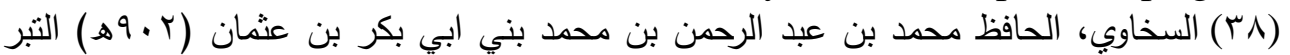

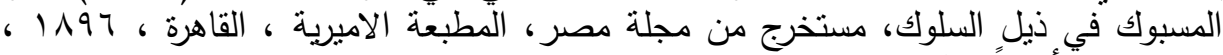

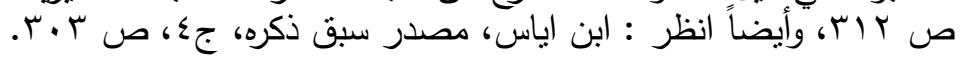

(*) About forty soldiers were responsible for the monitoring brothels in the city. In the middle of the seventeenth century, the man in charge of collecting taxes was called Amin Shikar. He continued collecting prostitution taxes till that job was banned in 1643.

(9) محمد بن أبي السرور البكري، الروضة المأنوسة في اخبار الدحروسة، تحقيق عبد الرازق

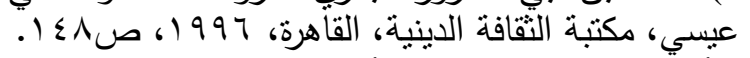

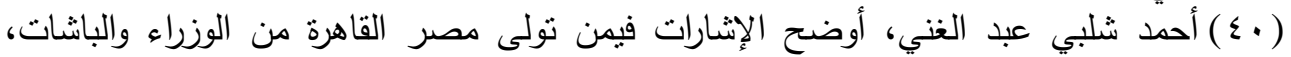

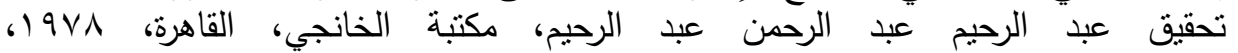

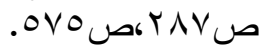

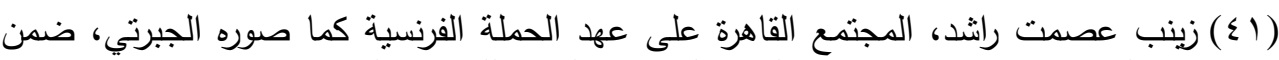

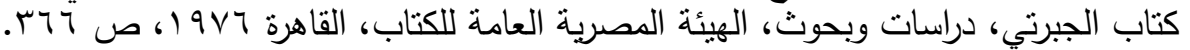

(*) On the occasion of the marriage of Ismaeel, Mohammad Aly made a big ceremony attended by professionals. There were decorations and caravans everywhere in Cairo. Dancers came from all over the country, and prostitution flourished. Pimps earned much more money during the ceremony which lasted for two weeks. This was encouraged by the huge 
troops sent by Mohammad Aly as a campaign against Alwahhabiyn . It was a chance for the soldiers to to be involved in prostitution and dissipation.

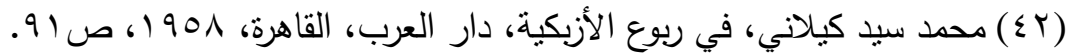

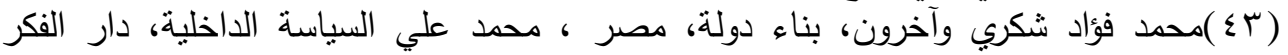

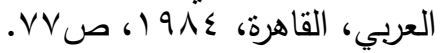

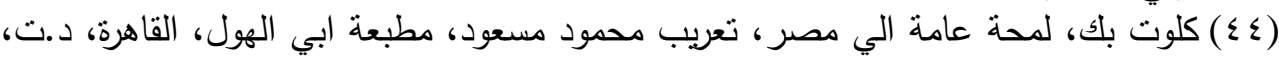

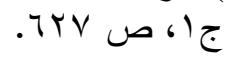

(*) The occupation issued public regulations including nine items recognizing prostitutes who should be medically examined once a week. This was followed by issuing laws and regulations for brothels, karakhanah. The policemen and health men should monitor over such brothels to provide recreation for the English soldiers.

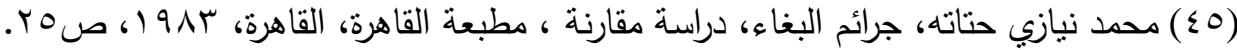

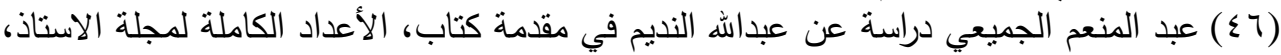

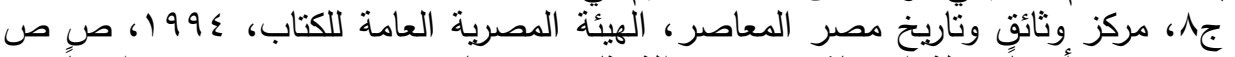

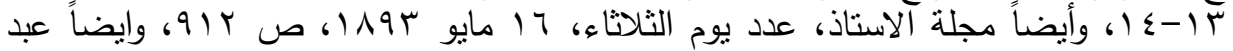
المنعم الجميعي، عبداله النديم ودوره في الحركة السياسية الاجتماعية، الكتاب الجامعي، القاهرة

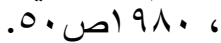

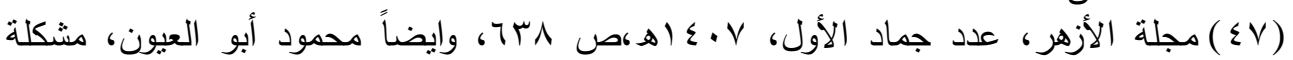

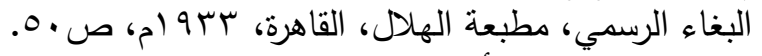

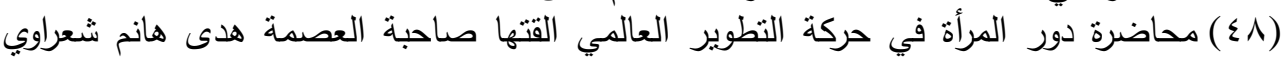

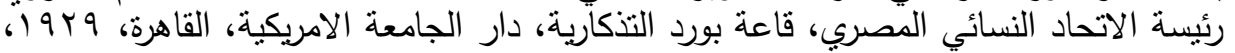

$$
\text { موقع الكنروني: مئن الاتحاد }
$$

http://modernegypt.bibalex.org/collections/Global/GlobalSearchResults. .aspx

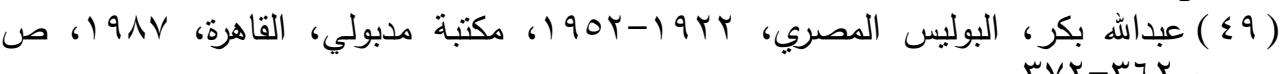

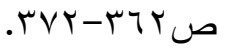

(*) This law includes 15 articles that ban all forms of prostitution . It also states penalties for prostitutes and pimps. Penalty should not exceed imprisonment for 3 months or a 300 pound fine. Penalties were severe in case of encouraging young boys and girls to be indulged in dissipation

(0) حسن المرصفاوي، المرصفاوي في قانون العقوبات تشريعاً وقضاء في مائة عام، منشأة

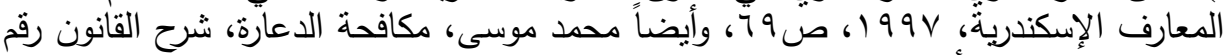

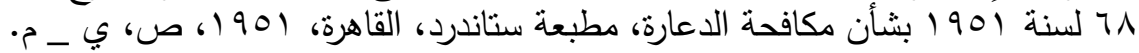

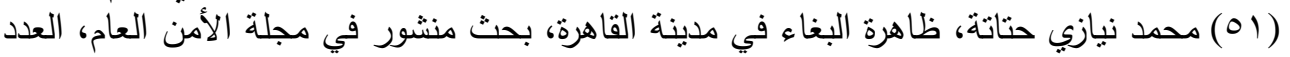

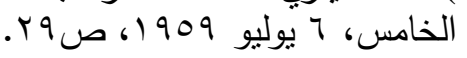

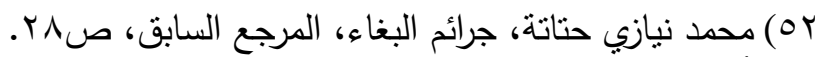

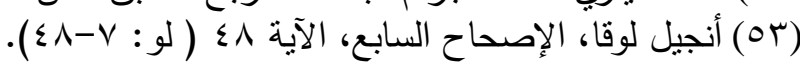




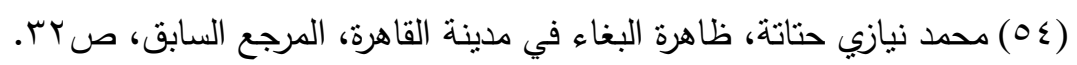

Also, Sacotte, M., la prostitution Correa, Paris, 1959, P.70.

$$
\begin{aligned}
& \text { (00) سورة النور، الآية r. }
\end{aligned}
$$

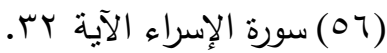

$$
\begin{aligned}
& \text { (OV) سورة النور الآية بر الآية }
\end{aligned}
$$

(01) محمد فيهم درويش ، الجرائم الجنسية وتأثيرها على ارتكاب الجرائم في جزء الثريعة والقانون،

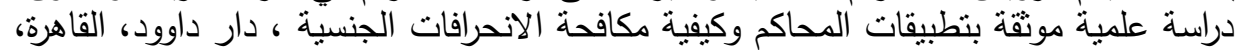

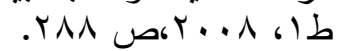

(*) Prophet Mohammad peace be upon him said, Oh, muslins, be aware of prostitution. In it are six characteristics, three in life, and three in the hereafter . In the world the purity of the face vanishes, a short age and an everlasting poverty. In the hereafter; the anger of Allah, subhanahu wa taalaa, severe punishment and fire tournament.

(ه9) البيومي اسماعيل الثربيني، النظم المالية في مصر والثام زمن سلاطين المماليك، الهيئة

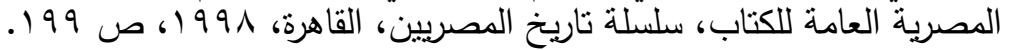

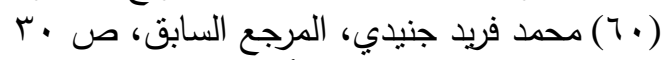

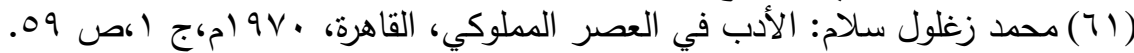

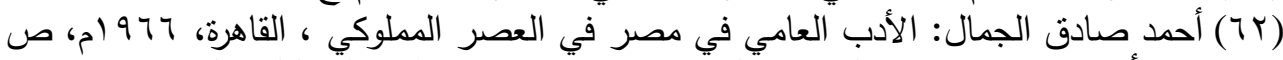

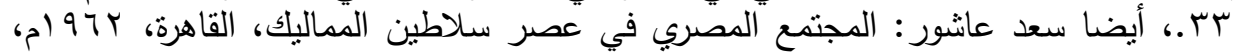

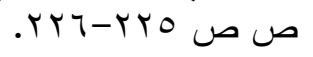

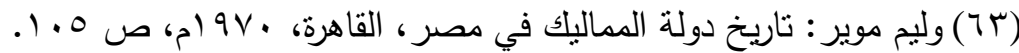

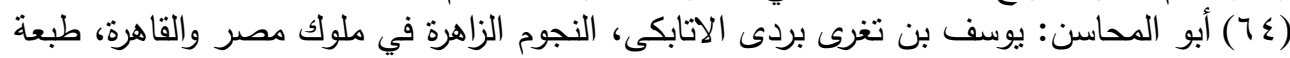

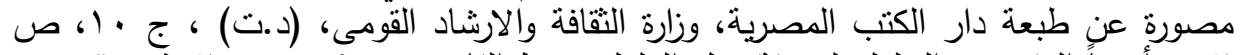

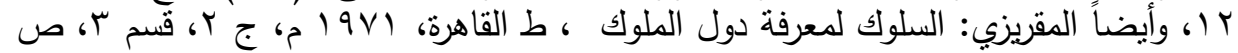

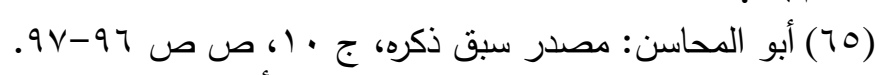

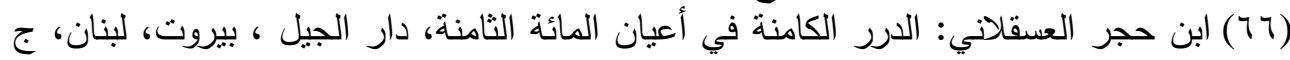

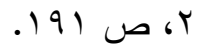

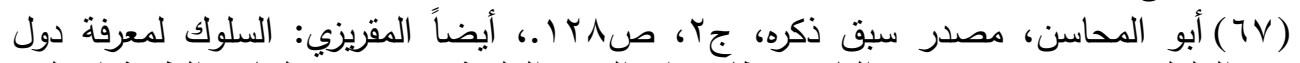

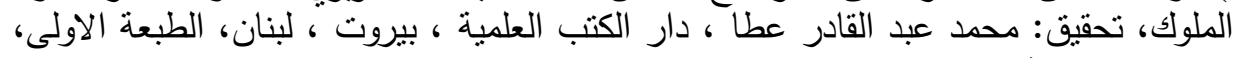

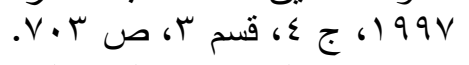

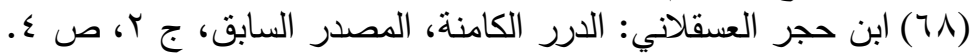

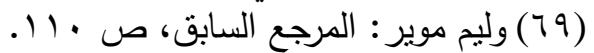

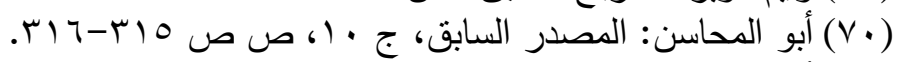

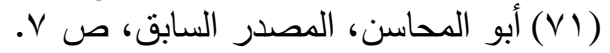

(*) jumdariyah is the person who helps the princess in dressing up. It refers to gama dar ; gama means dress in Persian, dar means the holder . Assubky said that the gemdars were smart young boys in which kings and princes were interested. They accompanied them till they slept. 
Kings and princes were extremely interested in such boys. The gemdars used very attractive clothes and decorations to appeal to the kings and princes.

(VY) السبكي، تاج الدين عبد الوهاب السبكى، معيد النعم و مبيد النقم، تحقيق: محمد على النجار

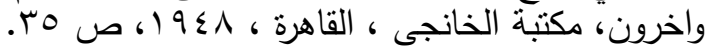

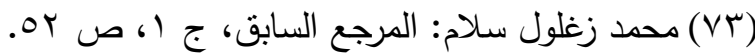

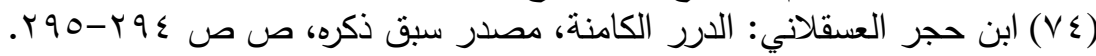

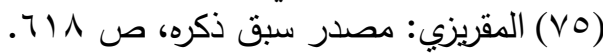

(*)The age of sultan Al-Nasser Mohammad bin Qaietbey was known for the abnormal. He was always accompanied by singers.

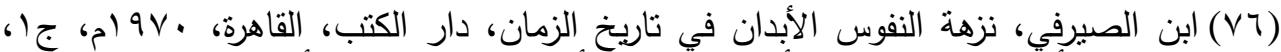

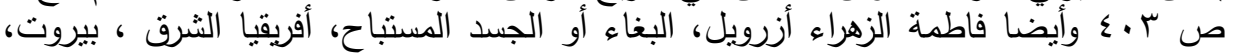

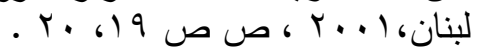

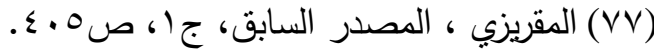

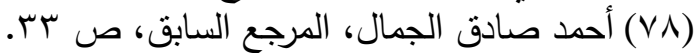

(V9) قاسم عبده قاسم ، دراسات في تاريخ مصر الإن، الاجتماعي، عصر سلاطين المماليك، ط؟،

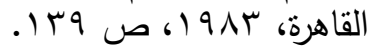

(*) He is sharaf Aldin Abou Saeed Hebatallah Ibn Mosaad El-Faezy, he was of Coptic origin then converted to Islam he was promated and became minister during the rain of king El-Moaaz Ebak who was pleased with him as he always consulted him.

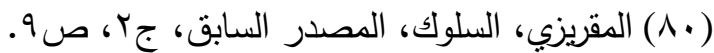

(*) They were old prostitutes whose goods were of no value

$$
\text { (1) محمد فريد جنيدي، المرجع السابق، ص سبر (1) }
$$

(*)The daminah was in charge of other women professions, contradicting prostitution . She was in charge of singers, readers, preachers, and cryers.

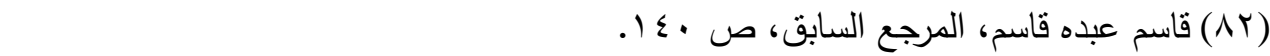

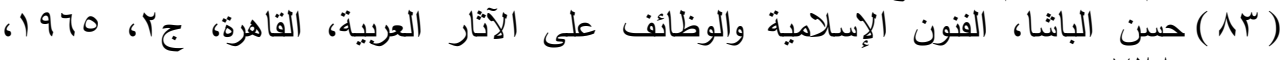

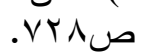

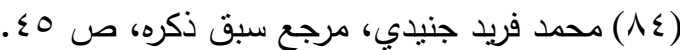

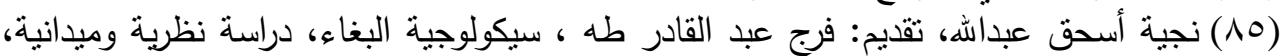

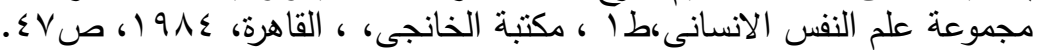

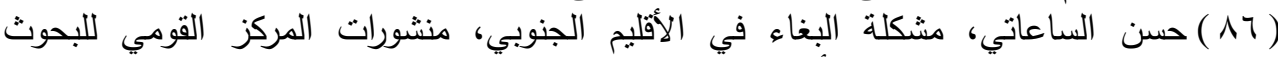

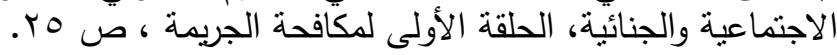

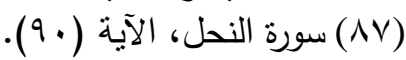

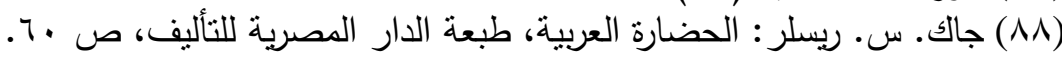

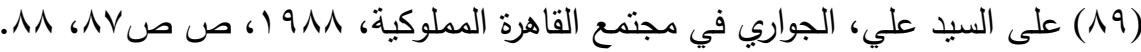




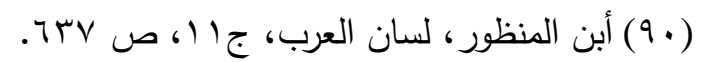

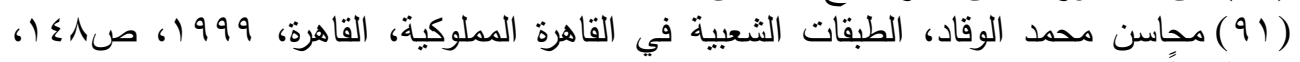

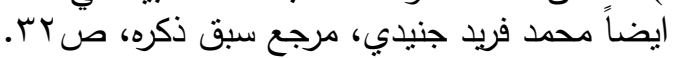

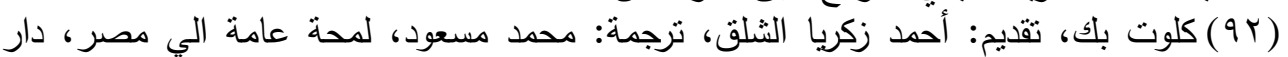

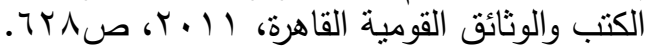

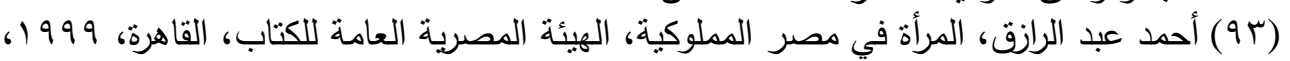
ص० r.

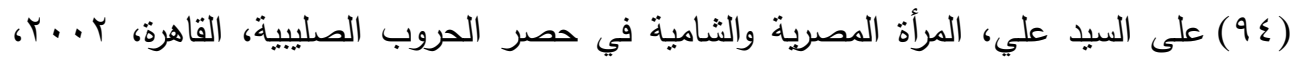

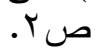

(90) النويري السكندري، كتاب الإلمام بالأعلام في ما جرت به الاحكام والأمور المقضية في واقعة

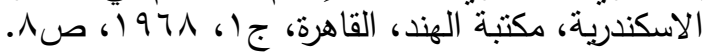

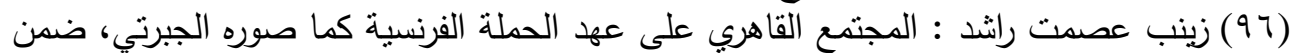

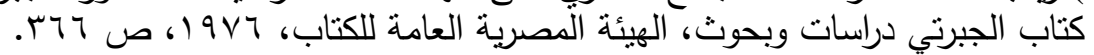

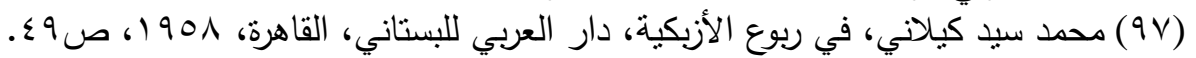

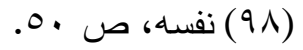

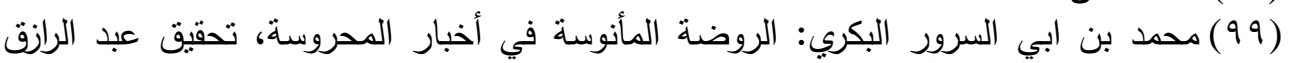

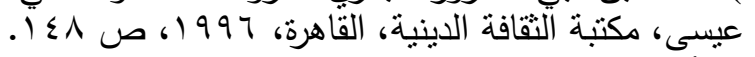

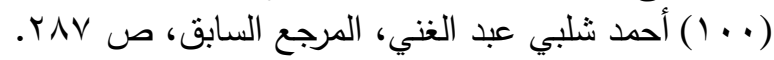

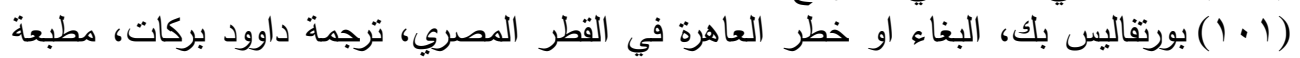

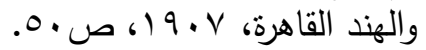

(*) Mikhanat was deravied form Turkish word (Mai)(Khana) means pubs wich stores and sell wines

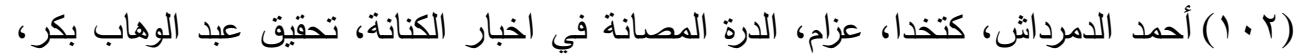

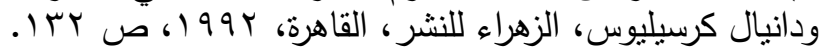

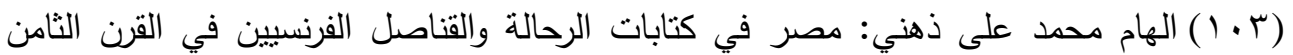

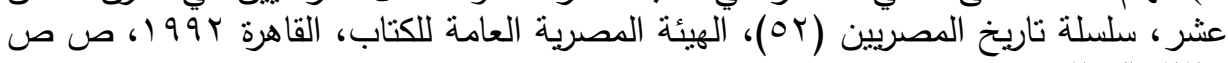
TOT ، YTV

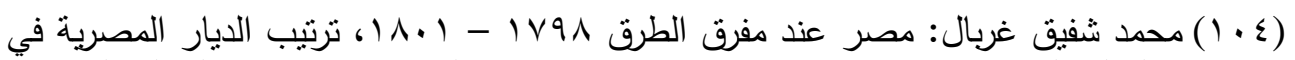

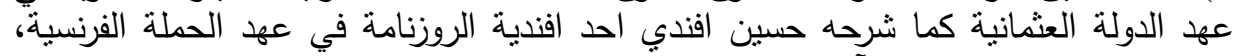

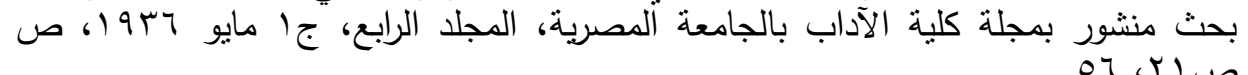

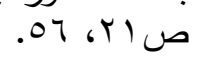

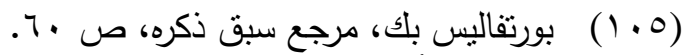

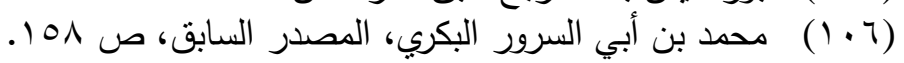

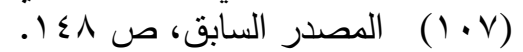

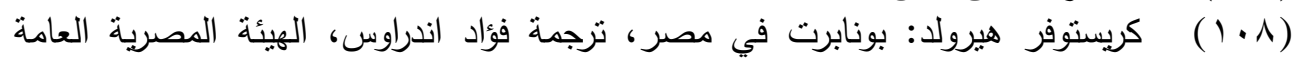

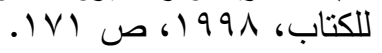

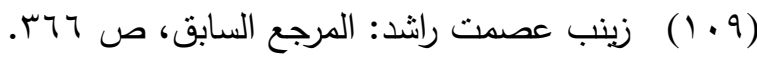

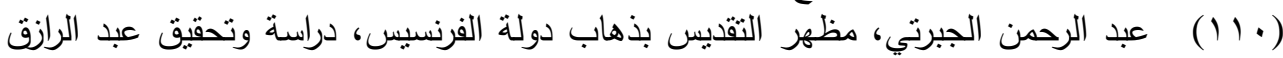

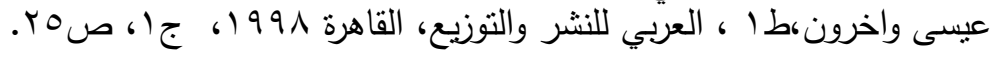




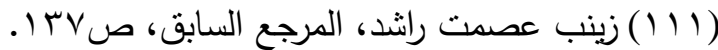

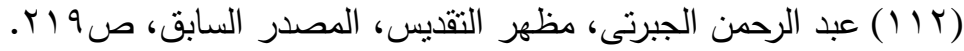

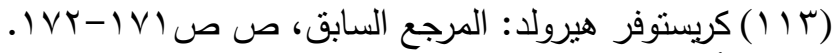

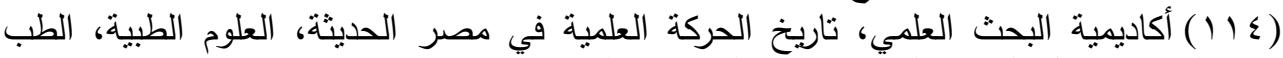

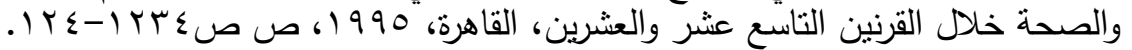

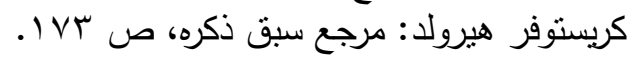

(*) Syphilis disease a sexually transmitted disease caused by Treponema palladium. It occurs due to sexual intercourse. It can be transmitted from mother to fetus in the uterus, or when crossing the child in the birth canal during delivery process. It may happen due to HIV. Gonorrhea disease caused by the bacteria Neisseria. It is transmitted from person to person via vagina, mouth, anus or sexual relations. It is rarely transmitted in case of safe sex using the condom. The incubation period is 2 to 30 days with most symptoms appearing between 4 to 6 days after infection. A few people may be infected without showing symptoms of Gonorrhea forever. 30- 60 percent of people infected may not show symptoms or without apparent symptoms of Gonorrhea.

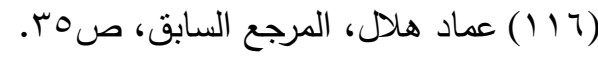

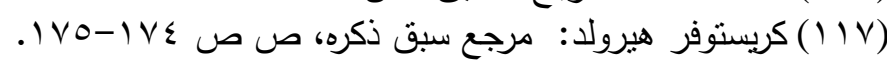

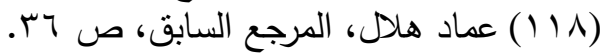

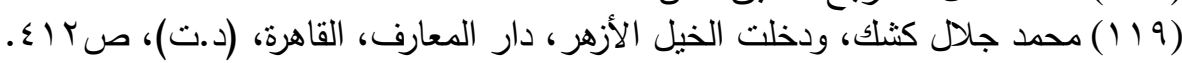

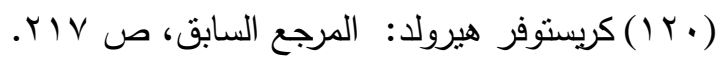

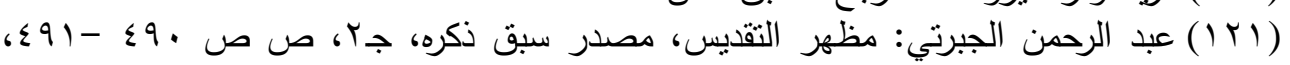

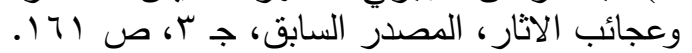

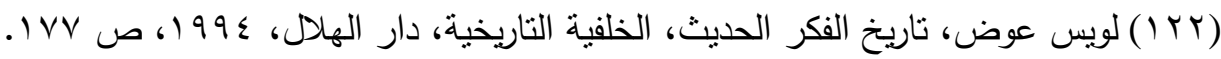

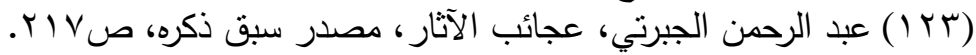

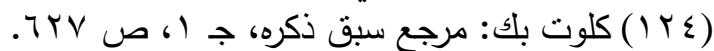

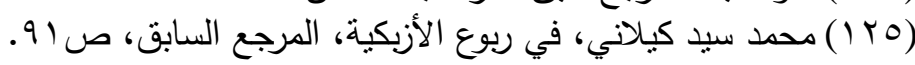

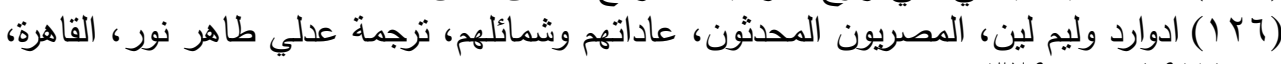
(9V

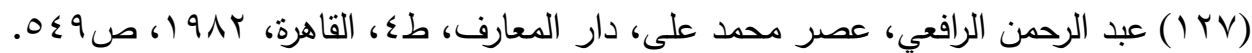

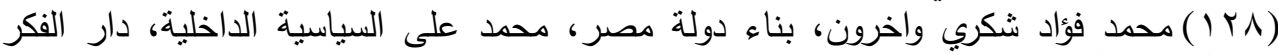

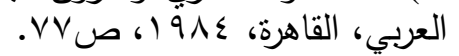

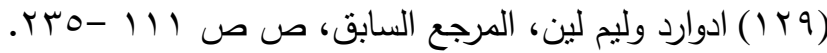

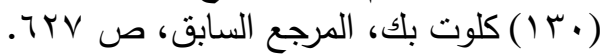

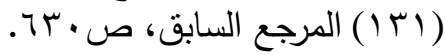

